„Kwartalnik Filmowy” nr 115 (2021)

ISSN: 0452-9502 (Print) ISSN: 2719-2725 (Online)

https://doi.org/10.36744/kf.562

(c) Creative Commons BY-NC-ND 4.0

Pawel Jaskulski

Uniwersytet Warszawski

https://orcid.org/00oo-0002-4380-2623

\title{
Filmy do czytania
}

\author{
Slowa kluczowe: \\ Andrzej Barański; \\ nowy kanon \\ kina polskiego; \\ film oświatowy; \\ animacja; \\ film dokumentalny; \\ kino \\ eksperymentalne
}

\begin{abstract}
Abstrakt
W rozmowie Filmy do czytania Andrzej Barański opowiada o mniej rozpoznanej stronie swojej twórczości. Tematem wywiadu są trzy filmy krótkometrażowe. Ich unikatowość polega nie tylko na łączeniu różnych technik - dokumentalnych, animowanych, oświatowych - lecz także na koncepcji zawartej w tytule. Potok (1985), Edukacja sentymentalna (1986) i Pobyt czasowy (2004) są filmami, w których pomimo zastosowanej ikonografii dominantę kompozycyjną stanowią słowa, hasła z leksykonu, instruktaże, dokumenty (podania, meldunki etc.). Widz otrzymuje możliwość „przeczytania” tych filmów, a w trakcie lektury może poszukiwać różnych tropów interpretacyjnych. Wywiad oprócz tradycyjnej warstwy informacyjnej charakteryzuje - zgodna z ideą i duchem dzieł - próba eksperymentu polegająca na „przeczytaniu” filmów wspólnie z reżyserem przez prowadzącego rozmowę. Pozwala to na wyeksponowanie znaczenia filmowych środków wyrazu, zwłaszcza sztuki montażu. Całość wpisuje się w badania nad mało dotychczas rozpoznanymi zjawiskami historii kina polskiego.
\end{abstract}


Andrzej Barański należy do najbardziej wszechstronnych autorów kina polskiego. Największą popularnością wśród widzów cieszą się jego filmy fabularne, zwłaszcza adaptacje prozy Stanisława Czycza (Nad rzeka, której nie ma, 1991), Marii Kuncewiczowej (Dwa księżyce, 1993), Dziennika we dwoje Jadwigi Stańczakowej (Pare osób, mały czas, 2005) oraz pracy zbiorowej Patron maluczkich. Brat Alojzy Kosiba pod redakcją o. Bogdana Brzuszka (Braciszek, 2007). Przywiązanie do literatury pięknej spoza kanonu jest znakiem szczególnym Barańskiego. Twórczość reżysera wykracza jednak poza kino fabularne. Ma on na koncie również liczne krótkie metraże, filmy dokumentalne i animacje. W dziełach tych - zrealizowanych najczęściej dla Wytwórni Filmów Oświatowych - reżyser pozwalał sobie na ekwilibrystykę formalna, nie unikając przy tym poważnej tematyki, choćby takiej jak dojrzewanie oraz poczucie wyobcowania (Wypracowanie, 1979 i Na wyjeździe, 1980). Dzięki Wytwórni Filmów Oświatowych Barański mógł spełniać aspiracje twórcy awangardowego, na jakiego zapowiadał się jako student szkoły filmowej w Łodzi.

Do najbardziej oryginalnych dzieł reżysera o takim charakterze należy zaliczyć: Potok (1985), Edukacje sentymentalna (1986) oraz Pobyt czasowy (2004). Sam twórca określa je mianem "filmów do czytania”. Podkreśla ono zarówno poczucie humoru reżysera, jak i faktyczną treść oraz spójność formalną tych krótkich utworów. Ich tworzywem są bowiem słowa, których zapis graficzny widać na ekranie. W przypadku Potoku pochodzą one z leksykonu popularnego w Polsce na początku XX w. Edukacja sentymentalna została oparta na wydanym w 1904 r. we Lwowie Podręczniku do nauki kaligrafii dla użytku szkolnego i domowego autorstwa Józefa Czerneckiego, Józefa Szablowskiego i Stefana Tatucha, a także na wzorach podań oraz pism urzędowych z lat 30. Z kolei Pobyt czasowy wypełniają blankiety serii dokumentów, które towarzyszą człowiekowi od dnia narodzin po śmierć.

Niniejszy wywiad ukazuje nieznane szerokiej widowni oblicze twórczości Barańskiego. Reżyser tłumaczy w nim genezę filmów do czytania, powody ich realizacji oraz znaczenie, które z kolei może stanowić pewien problem poznawczy w oderwaniu od intencji autorskich. Twórca nie ukrywa, że filmy te powstały poniekąd z kaprysu artysty, co nie pozostaje bez wpływu na sposób ich zrozumienia. Same w sobie burzą one przyzwyczajenia odbiorcze, toteż komentarz reżyserski stanowi w tym przypadku nieodzowną pomoc. W konsekwencji rozmowa z Barańskim przyjmuje dość eksperymentalną formułę. Trudno byłoby przeprowadzić w pełni tradycyjny wywiad dziennikarski na temat utworów tego rodzaju z zachowaniem standardowego układu pytań i odpowiedzi. Są one tu oczywiście obecne, ale dominantę rozmowy stanowi wspólna rekonstrukcja poszczególnych partii filmów. Główna zasada tego swoistego eksperymentu polega na odczytaniu list dialogowych, którym towarzyszą interpretacje, komentarze, uzupełnienia wyjaśniające. Dzięki temu czytelnik ma, paradoksalnie, możliwość poznania i zrozumienia dzieła filmowego bez projekcji. Koncept wywiadu oparty jest bowiem nie na streszczeniu, lecz na przeczytaniu całych filmów z uwzględnieniem analizy formalnej. Barański wskazuje konkretne środki gramatyki filmowej, dzięki którym osiągnął efekty dramaturgiczne. Szczególnie istotne były w tym przypadku: montaż, rytm, praca kamery, dźwięk, muzyka, narracja. Mowa w gruncie rzeczy o standardowym zestawie narzędzi, jakimi dysponuje każdy reżyser, niemniej w wymienionych dziełach Barańskiego występują one w nowych kontekstach. 
Reżyser przyjął skrajnie awangardową formę opowiadania, ale nie oznacza to pełnej hermetyczności. Omawiane utwory mają wprawdzie cechy sztuki dla sztuki, jednocześnie otwierają się jednak na finezję interpretacyjną. Pojedyncze słowa, całe dokumenty, podania, zastosowana ikonografia odznaczają się wewnętrzną logiką, co uwydatnia wywód Barańskiego. Obrana przez niego konwencja pobudza wyobraźnię. Słowa jako takie występują w roli głównej, przekazują konkretne idee, sytuacje, czy wreszcie ludzkie historie. Barański wykorzystuje je jako narzędzie do opowiadania o rzeczywistości.

Potok jest trwającym sześć minut filmem animowanym. Wartki nurt obmywa tu kolejne wybrane hasła z leksykonu w kolejności alfabetycznej. W finale potok przepływa dynamicznie przez listę wyrazów, po czym wpływa do kałamarza, w którym pióro zanurzy mały chłopiec uczący się pisać. W tym krótkim filmie zawiera się ogólna idea edukacji. Jej symbolicznym, a zarazem faktycznym początkiem jest litera "A". W ośmiominutowej Edukacji sentymentalnej można wydzielić trzy sekwencje. Pierwsza oraz druga dotyczą sztuki prawidłowego pisania zarówno pod względem kaligraficznym, jak i stylistycznym. W trzeciej tempo filmu gwałtownie przyspiesza. Barański za pomocą wykonanych w planie bliskim ujęć rozmaitych pism urzędowych opowiada dramatyczną historię bezrobotnego człowieka. Dokument Pobyt czasowy to właściwie mały dramat egzystencjalny. Śmiertelność, przemijanie widoczne w drukach urzędowych odnoszących się do kolejnych etapów życia człowieka, ma także cechy groteski.

Piotr Marecki w podsumowaniu wywiadu rzeki z Andrzejem Barańskim użył sformułowania twórcza wierność ${ }^{1}$ na określenie stosunku reżysera do adaptowanej literatury. Dzieła przedstawione w Filmach do czytania z jednej strony sac świadectwem skłonności artysty do eksperymentów awangardowych, z drugiej ujawniają typowe cechy jego stylu; tak jakby reżyser wykazał się twórczą wiernością wobec samego siebie. Barański filmami do czytania, podobnie jak dzieje się to w przypadku większości jego dzieł fabularnych, odwołuje się do światów minionych, korzysta z publikacji popularnonaukowych oraz dokumentów z początku XX w. Z dzisiejszej perspektywy są one reliktem epoki, co zawsze było dla twórcy jednym z najważniejszych powodów wyboru pierwowzoru literackiego. W kontekście Potoku reżyser mówi zresztą wyraźnie, że dla niego każdy stary leksykon stuży jako model wszechświata albo realizuje koncepcję świata jako biblioteki. Autentyzm cechuje Dwa księżyce Marii Kuncewiczowej, Życiorys własny robotnika Jakuba Wojciechowskiego, Wspomnienia wędrownego kramarza Edwarda Kozieła, Nim zajdzie księżyc Stanisława Czycza, będące literackimi zapisami przeszłości, prawdziwych wydarzeń, spotkań z realnymi osobami.

Filmy do czytania, które są oczywiście wyrazem popisu formalnego i zwrotu autotematycznego, wiążą się ściśle z artystyczną koncepcją Barańskiego z jeszcze jednego powodu. Chodzi o typ postaci. Twórca uwielbia bohaterów codzienności, domorosłych franciszkanów, prowincjuszy ciałem i duchem. Z uporem przypomina polskiemu widzowi o godności zwykłego człowieka. Echa tego pobrzmiewają zwłaszcza w Edukacji sentymentalnej. Rekonstrukcja losu pojedynczego człowieka, dokonana za pomocą serii oficjalnych pism zwiastujących jego kres, budzi skojarzenia z perypetiami kramarza Edwarda Chruścika (Kramarz, 1990), chłopaków „uwięzionych” w miasteczku w Nad rzeka, której nie ma, Andzi, czyli Kobiety z prowincji (1984), zabiedzonych autochtonów Kazimierza Dolnego 
w Dwóch księżycach. Wszyscy ci protagoniści żyją zgodnie z zasadą: prości ludzie nie maja historii, żeby zacytować jednego z nich - Witka z Niech cię odleci mara (1982). Ahistoryczne widzenie człowieka - cecha charakterystyczna fabuł Barańskiego - stanowi też fundament koncepcji Pobytu czasowego. Reżyser postrzega tu życie ludzkie jako chwilową obecność człowieka na ziemi - obecność, po której najczęściej zostaje jedynie ślad w postaci karty urodzenia i karty zgonu. Ważne, zdaje się twierdzić Barański, żeby przyjmować te bolesne fakty z pokora jak czynią to właśnie bohaterowie jego filmów, którzy zachowują się niczym postaci z wiersza Skreślona dedykacja Marcina Świetlickiego: wchodza i wychodza ciagle bohaterowie tego pogodnego dramatu².

P. J.: Roland Barthes wyznał kiedyś, że tak naprawdę wszystko, co pisze jest tylko poprawionym banałem. Według jednego z najczęściej poprawianych banałów film to sztuka obrazu.

A. B.: I dlatego kuszące jest zrobienie filmu ze słów.

P. J.: Ostatecznie słowo było na początku. Do tego słowo napisane to też obraz z akcentem na kaligrafię czy typografię, liternictwo.

A. B.: Ale ja myślałem o filmie ze słów zupełnie poza tymi kategoriami. Chciałem zrobić film wyłącznie ze słów do czytania, bez żadnego zalecania się do sztuk plastycznych. Najzwyczajniejszy druk, zupełnie niezwracający na siebie uwagi.

P. J.: Skąd się wzięła ochota na taki film?

A. B.: Mimo że zawsze opowiadałem obrazem, ewentualnie tylko zaopatrzonym w słowo, czyli tak jak być powinno, to czasami miałem chwile słabości. Kiedy dłużyło mi się kręcenie jakiejś sceny bez znaczenia, żałowałem, że nie załatwiłem tego jednym słowem w dialogu. Zwłaszcza gdy miałem nocne zdjęcia, kiedy było zimno i mokro; wtedy złorzecząc, myślałem, że słowami można więcej, szybciej i dokładniej powiedzieć, o co chodzi. Mówiłem sobie, że na tworzenie obrazów tracimy dużo czasu i pieniędzy, podczas gdy opowiadanie słowami jest proste i tanie, i siedzi się w bamboszach w ciepłym pokoju. Myślałem: słowo jest praktyczniejsze i celniejsze.

P. J.: Sprytne i ekonomiczne, ale jak to dokładnie rozumieć?

A. B.: O namalowanym stole - na przykład na obrazie van Gogha - można myśleć różnie, jest czasami całe kłębowisko myśli, często bardzo głębokich, ale jak się na kartce napisze samo słowo „stół”, to jednocześnie mówi się: ",to jest tylko stół, proszę nie zawracać mi głowy". To jest krytyka wywołana prostotą sytuacji, w rzeczywistości jednak nagie słowo „stół” jest trudniejsze, trudniej coś własnego wysnuć na jego temat. 


\section{Film pierwszy: Potok}

P. J.: Pierwszym filmem do czytania jest według pana Potok. A przecież jeszcze wcześniej, w 1980 r., był film Lexikon 32.

A. B.: Pomysł jest podobny, ale mamy do czynienia z zupełnie inną historią. Chociaż w Leksikonie użyłem języka niemieckiego, jego nieznajomość nie miała znaczenia - w odbiorze widza były to tylko nieme znaki graficzne. Do bezpośredniego czytania - być może wykrzyczenia - przeznaczyłem wyłącznie jedno słowo: „Hitler". Lexikon 32 klasyfikuję jako film zaangażowany, głośny protest przeciwko faszyzmowi, także film antywojenny. Natomiast filmy do czytania są zupełnie bezinteresowne, sztuka dla sztuki. Potok jest utworem w pełni do czytania, a jego przesłanie można uznać za wybitnie czytelnicze. Potok zrealizowałem na podstawie popularnego polskiego leksykonu z początku XX w. W kolejnych ujęciach pokazuję po jednym słowie - haśle z leksykonu, najczęściej pojawia się ono razem ze swoim odpowiednikiem rysunkowym. W kadr wcinają się też fragmenty tekstów otaczające nasze słowo hasło.

P. J.: Zrobiłem dokładną listę dialogową tego filmu do czytania. Inaczej trudno byłoby o nim dyskutować.

A. B.: Tak, to jest film do czytania. Nie można jednak porównać tego procesu do czytania książki w domu. Operuję językiem filmowym: montaż, ruchy kamery, ścieżka dźwiękowa, narracja filmowa, ekran, kino.

P. J.: Właśnie. Potok stanowi lekcję gramatyki języka filmowego. Początek filmu: z litery "A" $\mathrm{A}^{\prime \prime}$ wypływa atramentowy potok namalowany pędzlem, żyjący, migotliwy. Od razu wypływa on na strony leksykonu i opływa hasła, które znalazły się na jego drodze. Opływa je, jakby chciał ich dotknąć, zabrać ich cząstkę.

Aberracja-Akwedukt-Archipelag-Akwarium - Alkoholik-Anestezja-Amoniak - Balon - Baobab

Brzegi potoku cały czas się zmieniaja, raz jest on szeroki, po czym bardzo się zwęża, jego obrys pulsuje; na moment zatrzymuje swój bieg i po chwili wahania płynie dalej.

Bieg - Bulwar - Burak - Cegła - Cieśnina - Dalekowzroczność - Deszcz - Dok Drut - Dym - Działo - Echo - Gazy kiszkowe - Forma - Fotografia - Głowa - Głuptak

Potok wije się, gwałtownie zawraca, tworzy pętlę, przecinając swój bieg. Niespodziewanie skrapla się, istnieje w postaci kropli.

Hemoroidy - Herkules - Natrysk - Ibis - Smok - Inspekt - Jama - Jeleń - Jezioro - Jemioła - Jéz

Czasami potok się cofa, żeby wrócić do hasła pominiętego. Innym razem rozdwaja się, a w dalszym biegu pojawia się z dwóch stron i łączy. Przepływa też przez niektóre urządzenia.

Kamień - Kanat - Kapibara - Kartofel - Kaszalot - Katarakta - Kawka - Kino Kiszki-Kolumnada - Lama - Laryngoskop - Lampa - Latarnia czarnoksięska-Lody podbiegunowe - Lody - Lornetka - Łysina 
Nagle potok znika, nie ma go w kilku kadrach, po czym zjawia się z niespodziewanego kierunku.

Marzenie senne - Masaż - Miech - Mięso - Musujace płyny - Moździerz - Naftalina - Nerwy - Nostalgia - Oaza - Odmieniec - Ognie św. Elma - Ołówek - Orka

Jeśli nadarza się okazja, potok staje się częścią maszyny. Tak było, kiedy na drodze potoku znalazł się tzw. pas bez końca.

Pas bez końca - Pot - Pótwysep - Upust krwi - Sekretarz - Statek podwodny Świergotek - Tabaka - Tandem - Uwiąd - Wampir - Wyspa koralowa

Im bliżej końca, tym ostrzej potok przecina kadr, pionowo, na skos, na różnej wysokości.

Ważenie - Zachmurzenie nieba - Zapałki - Zatoka - Ziewanie - Żaby

Na koniec atramentowy potok szybko przepływa z góry w dół, przez spis haseł od "A" do "Z" i wlewa się do kałamarza.

W szkolnej ławce siedzi uczeń, umoczył pióro w atramencie, a następnie pisze w zeszycie pierwszą literę: „,a”. Cała wiedza z leksykonu znajduje się teraz w kałamarzu, ale żeby był ciąg dalszy, potrzebny jest jeszcze uczeń, który zanurzy w nim pióro. Dlaczego sięgnął pan po stary leksykon, a nie jakiś współczesny?

A. B.: Współczesne hasła byłyby widziane zbyt ostro. Hasła ze starego leksykonu mają już znaczenie przymglone, nawet te oczywiste, niezmienne. Dzięki tej mgiełce można tych słów używać w innym celu, a nie tylko w ścisłym związku $\mathrm{z}$ ich znaczeniem.

P. J.: A gdyby pracował pan nad Potokiem teraz, czy byłoby możliwe sięgnięcie na przykład po słowniki internetowe?

A. B.: Niestety, to już nie mój świat, takie wydawnictwa nie działają na moją wyobraźnię. Według mnie każdy stary leksykon służy jako model wszechświata albo realizuje koncepcję świata jako biblioteki. Może to być też - chociaż nie wiem dlaczego - jakiś prasłowiański cmentarz z widmami słów we mgle. W przypadku filmu Potok leksykon mogę porównać do zielnika z zasuszonymi słowami. Podróż po kartach zielnika kończy się żywą roślinką - literką „,a”.

P. J.: A czym jest tytułowy potok? Jaką funkcję pełni? Czy był konieczny? Wreszcie: czy można uznać w tym wypadku żywioł wody za symbol kina? Zaczarowuje nim pan zwykły świat.

A. B.: Potok jest czymś odświeżającym, jak wspomnienie pierwszego dnia w szkole podstawowej po wakacjach, nowe podręczniki. Potok to też początek czegoś większego, prze naprzód i wie, dokąd zmierza. U mnie od ", $\mathrm{A}^{\prime \prime}$ do „ $\mathrm{B}$, , od „, $\mathrm{K}$ ” do „L" i tak aż do "Z". Każdy potok kończy w jakimś morzu, tutaj morzem jest kałamarz. Cała wiedza z leksykonu do niego wpada.

P. J.: Poczucie humoru nie jest pierwszym skojarzeniem filmoznawców na dźwięk nazwiska Barański. A przecież uzupełnił pan o elementy komizmu większość swoich produkcji. W Potoku zauważam je chociażby w luźno potraktowanym wątku alkoholika. 
A. B.: Chyba już idea filmów do czytania dobrze świadczy o moim poczuciu humoru, choć niezależnie od tego samą ideę traktuję poważnie. Zajmowanie się starym leksykonem, poświęcanie mu czasu i uwagi świadczy o tym, że jednak muszę mieć jakieś poczucie humoru. Przypisuję wielką rolę swoim artystycznym badaniom i wizjom. Widzę chociażby globus, czyli kulę ziemską opisaną wyłącznie moimi hasłami z leksykonu, w miejsce nazw istniejących, a to by znaczyło, że hasła z tego leksykonu to jest cały świat, również południki i równoleżniki. Pisząc scenariusz, odczuwałem specyficzne odległości pomiędzy literami alfabetu, według którego ułożone są hasła. Te odległości nie są stałe, równe. Znałem przedwojennego geodetę przysięgłego, tylko on mógłby je zmierzyć. Wbrew pozorom jest to poważna sprawa, o ile tylko spojrzy się na nią z uśmiechem. Dzięki żartom często docieramy dalej.

P. J.: Czemu Potok tak nagle przyspiesza? Pańskie długie metraże słyną ze spokojnego rytmu. Tu jest zupełnie inaczej. Może to zabrzmi abstrakcyjnie, ale finał Potoku przypomina kino gatunkowe, na przykład sensację, w której w ostatnich sekwencjach trwa pościg za uciekinierem.

A. B.: Żadnej sensacji, raczej takie biologiczne odczucie, że na początku jest powoli, a potem coraz szybciej. Nawet wypracowania szkolne powstawały według tej zasady. Często jako dzieciaki wrzucaliśmy do potoku różne lekkie przedmioty: piórko, korek, kawałek patyka. Początkowo patyk kręcił się w kółko, jakby nie miał ochoty odpłynąć, ale po chwili porywał go nurt i patyk oddalał się coraz szybciej. Wytężaliśmy wzrok, żeby jak najdłużej go odprowadzać, przecież być może dopłynie do Warszawy, Gdańska, Bałtyku. Wszystko to były księżycowe pojęcia, wtedy żaden z nas jeszcze nie był nawet w Kijach ani Chmielniku. Na razie tylko patyk miał szansę zwiedzić kawał świata. W Pińczowie okoliczne potoki wypływały ze wzgórz, w ciasnych wąwozach gęsto zarośniętych. Żeby dotrzeć do źródła, trzeba było się przedzierać przez krzaki rosnące wśród wysokich drzew. Dzień był upalny, a tam chłód i cień. I trochę strach, jak w kościele. Natura potoku robiła wrażenie. Lumière?

P. J.: Zgodzi się pan z teza, że Potok ma w sobie coś z produkcji braci

A. B.: Jeżeli filmu nie robi się według innych filmów, tylko po swojemu, zaczynając od zera, jakby to był pierwszy film na świecie, to zawsze wyjdzie Lumière, to znaczy szczerość, ciekawość, oryginalność.

\section{Film drugi: Edukacja sentymentalna}

A. B.: W tym filmie najpełniej, jak gdyby w stanie czystym, zrealizowałem koncepcję filmu do czytania.

P. J.: Sprawdźmy. Na całość składają się trzy sekwencje, każda na podstawie innej książki.

A. B.: Można mówić o tym filmie przez te trzy książki. 


\section{Sekwencja pierwsza: Podręcznik do nauki kaligrafii}

A. B.: To jest najstarsza z książek, sam początek XX w. Zaczerpnąłem z niej głównie materiał dotyczący techniki pisania ręcznego: począwszy od papieru, przez przybory do pisania, aż do zaleceń, jak siedzieć.

P. J.: W istocie można się sporo dowiedzieć na ten temat. Dokonuje pan bardzo starannej selekcji: od rodzajów papieru po format zeszytów, o które - jak czytamy w Edukacji sentymentalnej - toczono zawzięte spory.

A. B.: Instrukcje są bardzo szczegółowe, trudno pobłądzić, a ja mam wrodzony szacunek do tego rodzaju twórczości. Nie kupię urządzenia bez instrukcji obsługi. Pozbawiony takiej pomocy nie odczuwam komfortu. Jak używam sokowirówki bez instrukcji, sok mi nie smakuje, nie mam do niego przekonania.

P. J.: Nie pominął pan instrukcji ostrzenia ołówka: Ołówek bierzemy do lewej ręki, zaostrzamy końcówkę, ale pisać możemy też rylcem i piórem.

A. B.: Uwagi dotyczące pióra są bardzo szczegółowe: Dla ręki starszej i cięższej odpowiedniejsze sa pióra twardsze. Rączki z kolei najlepsze są drewniane.

P. J.: Ważne jest częste odświeżanie atramentu. Nie może on być ani zbyt gęsty, ani zbyt blady.

A. B.: Mamy też ostrzeżenie. Pióro psuje się prędko i hamuje postęp. Wiem coś na ten temat, ponieważ w technikum budowlanym w Kielcach ćwiczyliśmy pismo techniczne. Wszystko szło pięknie, aż ze stalówki redisówki niespodziewanie spłynął kleks, a za to dostawało się kilka karnych kartonów do zapisania.

P. J.: Cenne są uwagi dotyczące pozycji ciała podczas pisania. Trzeba siedzieć bez przymusu, prosto i swobodnie. Ławki wcale nie dotykać. Głowa. Ramiona. Ręce. Zadaniem ręki lewej jest przytrzymywanie zeszytu. Pięty stóp maja być zbliżone.

A. B.: Wszystko jest ważne, jak w sporcie, na przykład w skokach narciarskich. W tej dyscyplinie wiele mówi się o pozycji dojazdowej, od ułożenia ciała skoczka na rozbiegu zależy dalszy ciąg. Tutaj też są szczegóły, które mają wpływ. Pochwalam takie rady i wymagania. Częściowo można je odczytać jako zalecenia dla filmowca. Teraz reżyser znacznie częściej przebywa na planie w pozycji siedzącej. Dawniej podczas ujęcia stał obok kamery, teraz siedzi w namiocie przed monitorem.

\section{Sekwencja druga: Stylistyka}

P. J.: W tej części pojawia się fundamentalne - choć myśli tak coraz mniej ludzi - pytanie: co to jest styl i od czego zależy. 
A. B.: Styl to człowiek, ale niejednokrotnie za styl bierze się jakiś pomysł techniczny albo odstępstwo od normy. Otóż styl to jest coś dużo głębszego, może nawet czasami mało widocznego, ale mocniejszego w wyrazie i ogarniającego wszystko. Styl bierze się z akceptacji siebie przez twórcę. Akceptacja własnego widzenia świata; z niej wynurza się taki, a nie inny styl. W przeciwnym wypadku reżyser nie może przekazać swojej prawdy.

P. J.: Dalej czytamy: Różnice stylu, zależne od tego, kto mówi. Zaledwiem wyszedt za dom, ujrzałem kilka wron, polujacych na dworskie kurczęta. Prawie w moich oczach jedna. Na ten widok zagrata we mnie krew przodków z pod Wiednia. Podkradtem się pod obórkę, zatliłem hubke, wymie-. Przez ten czas działy się ze mna nieopisane rzeczy. Wiele fragmentów pan urywa.

A. B.: To ma znaczenie muzyczne, służy również zainteresowaniu. Zdanie urwane jest zawsze ciekawsze, zyskuje dodatkową energię. Różnice stylu, zależne od tego, do kogo lub dla kogo mówimy (piszemy).

P. J.: Gdy adresatem jest dziecko, zdrobnienia są czymś naturalnym: Kochana Juleczko. Tatuś bardzo się ucieszył, że Julcia już tak ładnie pisze literki.

A. B.: Kiedy indziej styl będzie zależny od usposobienia autora (nastroju). Szkoda, że takie przywileje nie obowiązują w pracy na planie filmowym. Wyżej od usposobienia stawia się harmonogram zdjęć.

P. J.: Powitanie (z Beniowskiego): Ja sam się dziwię, że za bohatera wziałem takiego prostego szlachcica!

A. B.: Gramatyczno-logiczne przymioty stylu. Jasność. Czystość. Prezentuję je na przykładzie rozmowy starościny z mężem z Powrotu posła.

P. J.: Starosta: Nie chcesz się czem rozerwać? Siedzisz sama jedna. Starościna: Lubię sobie przez okno patrzeć na naturę.

A. B.: Pora na Wzniosłość.

P. J.: Najlepiej pokazać ją w rozumieniu XIX-wiecznym. Z pomocą przychodzą słowa ostatniego wielkiego poety romantyzmu Kornela Ujejskiego: Młodości moja, ty mi bądź aniołem! Młodości moja, bądź mi zbrojna tarczą!

A. B.: Fantastyczność.

P. J.: Każde dzieło sztuki wymaga fantazji.

A. B.: Tragiczność.

P. J.: Gdy ginie człowiek niepospolitych zdolności i sity ducha. Tragiczność spotykamy często w życiu. 


\section{Sekwencja trzecia: Wzory podań}

P. J.: Podstawę tej sekwencji stanowi książka Wzory podań z lat 30. Jak wskazuje tytuł, jest to zbiór wzorów podań na różne życiowe okazje. Została z nich utworzona hipotetyczna biografia człowieka, który korzystał z tej książki. Czas akcji: lata 30. XX w.

A. B.: W filmie korespondencja z urzędami, prowadzona za pomocą podań, skarg i próśb, mówi wszystko o kiepskiej sytuacji życiowej. Bohaterem nie jest konkretny człowiek, miejsca na dane osobowe nie zostały wypełnione; może nim być każdy, na przykład mój wujek, dziadek, który miał wtedy trzydzieści lat. Chociaż w gruncie rzeczy postać tę możemy postrzegać jako uniwersalna, ponadczasową. W pewnym sensie jej kłopoty życiowe można też odnieść do tragicznych postaci wielkiej literatury. Inaczej rzecz ujmując - wyobraźmy sobie, że te wzorce podań dotyczących człowieka w biedzie istniały już od początku świata. Chodzi właśnie o takie formularze do uzupełnienia przez osoby z kolejnych pokoleń, stuleci czy tysiącleci. Mogą one wpisać się tam imieniem i nazwiskiem, imieniem matki i ojca. Znaczy to ni mniej ni więcej, że bieda jest zawsze ta sama, zmieniają się tylko jej stołownicy.

P. J.: Pisma są pokazywane w całości i we fragmentach, do czytania są zdania, a czasami tylko słowa wyciągnięte z pism. Przeważnie każde z nich stanowi w filmie oddzielne ujęcie. Pisma, zdania, słowa są cięte, urywane według pisowni filmowej, czyli sztuki montażu budującej dynamikę obrazu.

A. B.: Podaniowa epopeja zaczyna się od skargi do władz miasta: Do Magistratu miasta (wypisać nazwę). Wydział Budownictwa (imię i nazwisko petenta) zamieszkałego przy ul... nr... Wszystko tak jak obecnie, dzisiejsza epopeja mogłaby się tak zaczynać.

P. J.: W pierwszym podaniu petent pisze: Sufity w moim mieszkaniu zaciekaja, tynk odpada z sufitów i ścian. W następnym piśmie lokator prosi o usunięcie wilgoci z jego mieszkania: Od pewnego czasu ściany zaszły wilgocia. Ponieważ wtaściciel domu pomimo mej prośby, nie podjąt. (Podpis).

A. B.: Ustęp podwórzowy też pozostawia wiele do życzenia. O tym problemie pisze już nie tylko w swoim imieniu.

P. J.: Zagraża nie tylko zdrowiu, ale i życiu, ponieważ przegnite deski podłogi groża załamaniem się. W imię bezpieczeństwa publicznego. (Miejscowość i data). (Podpis).

A. B.: Bohater nie tylko upomina się o swoje mieszkanie, ale i protestuje, kiedy właściciel fabryki nie przestrzega ustawy o ośmiogodzinnym dniu pracy; domaga się $\mathrm{w}$ tej sprawie interwencji.

P. J.: Do Pana Inspektora Pracy. Na kilkakrotne nasze zwracania się w tej sprawie 


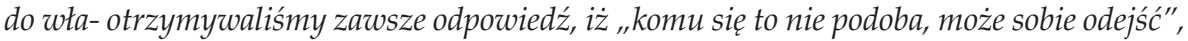
w ogóle zaś jak właściciel, tak i majster. (Zwiazek prosi Inspektora Pracy o pośrednictwo w załagodzeniu zatargu).

A. B.: Nasz bohater w poszukiwaniu sprawiedliwości udaje się do sądu. Jeszcze jest idealistą, wierzy w sprawiedliwość dla każdego.

P. J.: Pracownik występuje o odszkodowanie za pracę w godzinach pozasłużbowych: Do Sadu Pracy. SKARGA POWODOWA. Abym pozostawał dłużej ponad, za co otrzymam specjalne wynagro-1) zasadzić od pozwanej firmy na moja korzyść zł... gr... z odsetkami prawnemi.

A. B.: Niestety, nie było trzymiesięcznego wymówienia. Zamiast zwrotu należnego wynagrodzenia został zwolniony z pracy.

P. J.: Bohater pisze: Zwolnit mię z zajmowanego stanowiska, jako powód zły stan interesów w swojej firmie. Odmówit mi wyptacenia wynagrodzenia. Mam zaszczyt prosić Sąd. (Podpis). Następnie sprawa karna o obelgi czynne. Kiedy upomniał się wprost, sprawy przybrały jeszcze gorszy obrót: Nagle uderzyt mnie. Krwotok. Załaczając świadectwo lekarza. Do odpowiedzialności karnej. (Podpis).

A. B.: I tutaj zaczyna się odyseja bezrobotnego w poszukiwaniu pracy. Najpierw blisko i z wymaganiami, ale wkrótce: może być i daleko, i bez wymagań, byle mieć pracę, może być jakakolwiek.

P. J.: Dowiedziawszy się o wakujacej w firmie W.P. posadzie. Im swoje ustugi. (wymienić wyksztatcenie), (wypisać stanowisko), gdzie pracowałem, przez co zostatem bez posady, obecnie zaś. Załązając odpisy świadectw. W.P. przychyla się do mojej prośby, ja zaś ze swej strony akuratnościq i pilnościa zyskać zaufanie W. Panów. (Podpis). Odpowiedź przychodzi, ale odmowna: Niestety, rzeczona posada jest już zajęta. Odyseja trwa.

A. B.: Nie ma pracy, nie ma pieniędzy. Zaczynają się kłopoty. Przychodzi wezwanie: Gospodarz wzywa lokatora do zapłacenia komornego. Bezrobotny zwraca się do magistratu, jeszcze z tej strony może przyjść pomoc.

P. J.: Prośba o wydanie zaświadczenia o pozostawaniu bez pracy dla uzyskania ewentualnego odroczenia eksmisji. Na zasadzie wyroku Sadu Grodzkiego z dn... wyznaczono mi eksmisje z zajmowanego dotąd mieszkania w domu. Ponieważ od wyroku Sądu Grodzkiego wniostem apelację.

A. B.: Poszukiwanie pracy bezrobotny musi rozszerzyć na cały kraj, podróże kosztuja, a on nie ma na bilet. Prośba: O wydanie nowej legitymacji dla bezrobotnego. O wydanie zaświadczenia dla bezrobotnego na prawo do 50\% zniżki kolejowej.

P. J.: Napięcie narasta. Przychodzi pora na kolejną prośbę: O przyznanie jednorazowej zapomogi z funduszów państwowych nieuprawnionemu do jej pobierania. Do Pana Przewodniczacego Zarządu Obwodowego Funduszu Bezrobocia. Będąc zredukowa- 
nym w roku... przez firmę... w..., nie mogac znaleźć pracy w rodzinnym mojem mieście, przyjechałem do... I tutaj, mimo miesięcznego poszukiwania, pracy nie znalazłem. Oszczędności wyczerpują się z dnia na dzień, grozi mi przeto eksmisja, jako też głód. Ponieważ nie jestem ubezpieczonym. (Podpis).

A. B.: Sytuacja stała się krytyczna. Nawet gospodarz domu chce mu pomóc.

P. J.: Gospodarz domu wystawia lokatorowi zaświadczenie o ubóstwie: $\mathrm{Ni}$ niejszym zaświadczam, żadnych niemal środków. Materialne położenie. Zaś swojem nienagannem prowadzeniem bezwzględnie na poparcie. Prawdziwość powyższego stwierdzam własnoręcznym podpisem.

A. B.: Bezrobotny stracił już nadzieję, że znajdzie normalną pracę. Postanowił zająć się drobnym handlem.

P. J.:W kolejnym podaniu prosi o pozwolenie na handel starzyzna, a konkretnie używaną garderobą męską i damską.

A. B.: Ale i tutaj nie jest łatwo, już na początku pojawiły się trudności. Między bezrobotnymi również występuje konkurencja i walka. Wkrótce musi napisać odwołanie.

P. J.: Odwołanie od decyzji Zarządu Obwodowego Funduszu Bezrobocia. Zostałem pozbawiony zasitku, ponieważ rzekomo trudnię się praca dorywcza. Zarząd opart się na doniesieniu. Decyzje te uważam za niestuszna i wysoce mnie krzyw-.

A. B.: Kompletnie zrezygnowany, chce emigrować. Pisze podanie:

P. J.: O wydanie bezptatnego emigracyjnego dowodu osobistego.

A. B.: Do emigracji nie doszło.

P. J.: Sytuacja staje się krytyczna. Bohater podupada na zdrowiu, ale nie ma środków na leczenie. Jest zmuszony wystosować podanie do miasta o pokrycie kosztów pobytu w szpitalu.

A. B.: Autorem ostatniego pisma nie jest już nasz bohater.

P. J.: Raport przodownika o samobójstwie. Udałem się natychmiast. Po przyjściu na miejsce wypadku na sznurze, założonym na gałęzi drzewa, kazałem odciać i złożyć opodal na trawie. Przeszukatem kieszenie ubrania i znalazłem: scyzoryk, zapalniczke i guzik.

A. B.: Zdjęcie guzika na cały ekran. Wcześniej w kilku miejscach, w tle, na pół ekspozycji, zupełnie widmowo, już pojawił się ten guzik.

P. J.: Wysublimowana zapowiedź tragedii. Na dodatek dramat bohatera po- 
zostanie tajemnica, ponieważ z raportu jasno wynika, że wobec braku świadków, przyczyn samobójstwa ustalić nie można.

A. B.: Zastanawiający jest ten ostatni wzorzec pisemnego skwitowania samobójstwa. Autor poradnika Wzory podań kierował się przecież najczęściej występującymi tematami podań, skarg, oświadczeń. Z ich treści, rozwoju, musiał wyczytać, dokąd to wszystko prowadzi, stąd na koniec nie inny, tylko taki wzorzec. Jak zwykle wystarczy tylko wpisać brakujące dane denata. Dla mnie Wzory podań to poemat tragiczny.

P. J.: Są silnie dołujące.

A. B.: Jest w tym coś fatalnego, jakieś społeczne fatum. Ta książka jest dla tych, którzy sami nie potrafią pisać. Uważaja, że tego rodzaju pisma, ich język i forma są z zupełnie innego świata, jakaś łacina. Zwłaszcza że takie pismo trzeba ułożyć. Szkoda nawet próbować.

P. J.: Jak zareagowano w Wytwórni Filmów Oświatowych na ten film? Czy była to praca zlecona, czy też propozycja wyszła od pana?

A. B.: Film przyjęto dobrze, ale bez pełnego zrozumienia jego sensu, widziano go raczej jako popis formalny. To znaczy nikt na serio nie przejął się dramatem tamtego człowieka. Spokojnie też przyjęto ten symboliczny guzik, który się odpiął, może urwał, człowiek wpadł do czarnej przepaści i jeszcze leci, spada na zawsze. Ale rozumiałem tę wyważoną reakcję - przecież ten bohater był papierowy. Szukanie bohatera w tego rodzaju książce przypomina popisy aktorki Heleny Modrzejewskiej czytającej książkę telefoniczną z całą gamą przeżyć, niczym łzawy melodramat. Gdybym realizował zlecenie, nie mógłbym pozostać taki artystowski. To nie była praca ani filologiczna, ani socjologia, ale wyłącznie moja liryka filmowa. Do tego dla mnie mocna życiowo, chociaż papierowa, a raczej: właśnie dlatego, że papierowa. Ten pożółkły papier i byle jaki druk - to była najtrafniejsza sceneria dramatu. Na mnie robi wrażenie milczenie zadrukowanej kartki, jak gdyby wstrzymującej się od głosu.

P. J.: Pan jednak zabrał głos.

A. B.: Na życie tego człowieka patrzę bardzo osobiście, zapewne też nie dałbym rady. To równia pochyła, na której nie można się zatrzymać. I ten guzik w kieszeni, oskarżenie pod adresem społeczeństwa: „Tylko tyle od was dostałem”. Dla mnie to jest więcej niż fabuła czy dokument, mamy tu dosłownie, czarno na białym, urzędową drogę do przepaści, którą wyznaczają podania, zaświadczenia, prośby, odwołania, oświadczenia.

\section{Film trzeci: Pobyt czasowy}

A. B.: Ledwie człowiek przyjdzie na świat, a już rusza lawina papieru, który formuje się w drobiazgową dokumentację. Jeden papierek wywołuje drugi, cały czas łańcuch ten się rozgałęzia, potężnieje, nabiera mocy, zaczyna żyć swoim życiem, 
jeden dokument - często już bez udziału osoby - powołuje się na drugi dokument. Cały czas trwa proces powtórkowy, przypominanie i utrwalanie: imię i nazwisko, imiona rodziców, data i miejsce urodzenia, wyznanie, stosunek do służby wojskowej... Człowiek w coraz większym stopniu staje się zależny od towarzyszących jego życiu papierów, które chcą wiedzieć o każdym jego kroku, upominaja przypominają ponaglaja groża, ścigaja, karzą. Od aktu urodzenia, przez akt ślubu, aż do aktu zgonu za człowiekiem suną pouczenia, deklaracje, meldunki, wyszczególnienia, rejestry, wyciągi, poświadczenia, księgi kontroli, zawiadomienia, ankiety A, B, C, D; dochodzenia, wezwania, doniesienia, nakazy. I tak aż po kres żywota i kres papierów, bo któregoś dnia zostają one zniszczone. Najbardziej uniwersalne i elementarne są dokumenty dotyczące przyjścia na świat, pobytu i przemieszczania oraz zejścia ze świata. Układają się one w swoisty życiorys każdego, niezależnie od wyznania, wykształcenia, a nawet epoki i kontynentu, na którym przyszło żyć. Z otwartych na każdą ewentualność, niby suchych rubryk formularzy wyziera prawda o kondycji człowieka, o jego pobycie czasowym.

P. J.: To chyba najbardziej przygnębiający film do czytania. Ponura lektura. A gdzie miejsce w twórczości Andrzeja Barańskiego na eskapizm?

A. B.: Można powiedzieć, że jest to film o umieraniu, tylko nie w sypialni czy na łóżku szpitalnym, ale w dokumentach. To jest też śmiertelna droga dokumentów do celu, gdzie zostaną nieuchronnie zniszczone. Ale żeby człowiek mógł spokojnie zejść ze świata, musi wypełnić niezliczoną ilość druków, druczków. Kiedy wypełni jeden, gdzieś czeka już na niego następny. Nie jest to jednak film smutny. W ogóle zajęcie się tym tematem, do tego w ten sposób, wyraża tylko mój smutny uśmiech.

P. J.: Głównym obiektem są blankiety meldunkowe, ewidencyjne, druczki, przeróżne formularze towarzyszące ruchom obywatela w okresie między świadectwem urodzenia i świadectwem zgonu. Obfitość dokumentów podkreśla litania albo mantra powtarzających się haseł: zameldowanie, wymeldowanie, zamieszkał, wyprowadził się, ulica, numer domu, imiona rodziców, stosunek do służby wojskowej, wyznanie, przynależność państwowa, dowód osobisty, własnoręczny podpis, pieczęć urzędu, dokument wydany dnia, ostatni adres, przybył dnia, zawarli związek małżeński, rejestr mieszkańców, zgodność z oryginałem, stawiennictwo obowiązkowe, itd., itp. W warstwie obrazowej udostępnia pan te wszystkie formularze, analizuje je oraz tworzy wariacje formalne na ich temat. Ważnym elementem są ryciny i fotografie. W warstwie dźwiękowej wybrzmiewa nieustająca litania głosów różnych ludzi czytających i wypełniających rubryki, cała rodzina człowiecza. Słyszymy przede wszystkim język polski, ale są też fragmenty w innych językach, nawet egzotycznych. W filmie występuje rozbudowana ikonografia: mapy, rośliny, miasta, morza, pustynie, dzieła sztuki, portrety generałów, geniuszy, górników, sportowców, aktorów filmowych, rolników, żołnierzy, przechodniów. Jest to ikonografia odsyłająca do różnych epok, różnych stron świata, całej ludzkości - starożytna Grecja, jesień średniowiecza, pierwsza wojna światowa i inne wojny, cały "pobyt czasowy” ludzkości i człowieka, cywilizacji i pojedynczych ludzi. Ankiety i inne kwestionariusze meldunkowe są pokazane 
w różnych planach aż do zbliżeń poszczególnych słów, wprowadza się je ruchem kamery, przenikaniem, cięciem. Ta warstwa obrazu wydaje się nadrzędna.

A. B.: Użyte w filmie blankiety i formularze pochodzą z ubiegłego wieku, dzisiaj już nie zawsze są papierowe, tylko elektroniczne, ale cele i zasady pozostały jak dawniej. I najdawniej. Przecież już Józef z brzemienną Maryją chciał dać się zapisać. Film otwiera jednak sekwencja kosmiczna: Droga Mleczna, Galaktyka Andromedy, Plejady, Perseidy, spadające meteoryty, kratery Księżyca...

P. J.: Można też ująć to inaczej i powiedzieć, że właściwa narracja zaczyna się od człowieka, który podjął się prowadzenia meldunków. Kim jest ten człowiek?

A. B.: Oczywiście można go widzieć jako kogoś z biura Pana Boga, ze skrzydłami, ale ja widzę go inaczej, jako zwyczajnego człowieka, który chce sobie dorobić parę groszy albo po prostu ma taki obowiązek jako właściciel czy najemca. Chyba że to boski dostojnik kamufluje się pod postacią szaraczka w marynarce z wytartymi łokciami. Są i inne warianty, ale wygląd pozostaje bez zmian: jest spocony i ma ciężki oddech palacza. Nie nawykł do pisania, ciężko mu idzie, ale to tylko domysły - nie ma żadnego pisania, miejsca wykropkowane w formularzach pozostają niewypełnione. Cały film opiera się na blankietach i formularzach niewypełnionych. W tym tkwi istota tego tematu i jeśli coś mnie w nim przeraziło, to właśnie te miejsca niewypełnione, pustka kosmiczna, zionąca, a przynajmniej wyrwa, mrok i bezdenność. Byle nie wpaść. Jeśli wpisze się tam nazwisko, to tak jakby utworzyło się pajęczynę nad dziura, ale jeśli je dodamy, wychodzi jeszcze gorzej, niż gdyby nic nie było.

P. J.: Czyli postać żywcem wzięta z pana filmów fabularnych. W Pobycie czasowym prowadzący meldunki nie pojawia się fizycznie, pierwsze skrzypce grają dokumenty.

A. B.: I widz ma możliwość przeczytania ich od początku. W obrazie jest druk deklaracji i wybrane z niej zdania. Teksty z wytłuszczonymi literami są czytane przez lektora. Deklaracja. Właściciela (niepotrzebne skreślić)/dzierżawcy domu przy ulicy... nr... Ja, niżej podpisany... właściciel (niepotrzebne skreślić)/dzierżawca domu zawiadamiam, że meldunki na moim własnym (niepotrzebne skreślić)/zarzadzanym przeze mnie domu prowadzić będę osobiście. Upoważniam synalcórkę (niepotrzebne skreślić) do wszelkich czynności zwiąanych z prowadzeniem meldunków w wyżej wymienionym domu. Komunikuję, że treść rozdziału piątego rozporzadzenia o ewidencji i kontroli ruchu ludności jest mi dokładnie znana. Miejsce urzędowania dla prowadzącego meldunki wyznaczyłem w lokalu nr... mego domu. Często zdania urywają się w pół słowa, jest to efekt dynamicznych, "filmowych" cięć montażowych tekstów.

P. J.: Następny dokument: „Rejestr domów”.

A. B.: Pozwolę sobie na dygresję. Przez całe lata dom rysowałem jako coś niezwykle prostego, taki najbardziej elementarny atom z życia ludzi: ściany, dach, komin, okno, drzwi i to wszystko; a jak jeszcze dorysowałem dym z komina, dom 
ożywał. Teraz ten mój dom ma wnętrze, jest nim kłębowisko linii tworzących poplątany, ciasny kłąb. Kłąb jest w stałym ruchu, wierci się, oddycha, zmienia kształt, zamiera na chwilę i na dłużej. Napiera na okno, na drzwi, ale nie ma ochoty opuścić naszego domu. Nie jest to ujęcie obyczajowe, tylko pochodzenia kosmicznego. Ten kłąb linii współtworzą kable i kabelki, gdy przyjdzie śmierć, powiedzą: „Szczęśliwej drogi". Żyjąc wśród kabli, cierpimy, dlatego na koniec coś się nam należy. W filmie tego domu nie ma.

P. J.: Są za to twarde, sprowadzające na ziemię dane. Do najważniejszych należą: miejscowość, ulica, numer domu.

A. B.: Do tego tematu dołączyłem bogatą ikonografię. Domy z różnych epok i obszarów: elegancka miejska willa z początku XX w., skandynawski wiejski dom też z tego okresu, wielki, groźnie wyglądający gmach w stylu neogotyckim - chyba jakiś ważny bank amerykański - następnie przenośne chatki afrykańskich koczowników, hodowców bydła, wysoki budynek mieszkalny z wielkiej płyty, średniowieczny zamek obronny, pałac fabrykancki z końca XIX w., zabudowa miasta z XVIII w., afrykańskie szałasy z gałęzi i traw. Co jakiś czas pojawia się wtopiony w obraz tytuł druku: „Rejestr domów - miejscowość, ulica, numer domu”.

P. J.: Skąd taki niespotykany rozmach w czasie i przestrzeni?

A. B.: To jest poetycka megalomania, korzystam z takiej wolności. Wolno mi coś takiego zrobić, za pomocą najtańszych materiałów opowiedzieć największą historię, stworzyć megaprodukcję. Druki biurowe służące do ewidencji ludności oraz ilustracje ocalałe ze zniszczonych książek - tylko tyle, a poruszam się jak panisko po całym globie, po historii ludzkości i odważnie usiłuję sklecić własne zdanie.

P. J.: Lista osób zamieszkałych w domu przy ulicy... numer... miejscowość... powiat..., nazwisko i imię głównego lokatora... Wyszczególnienie osób - nazwisko i imię, imiona rodziców, nazwisko panieńskie matki, data i miejsce urodzenia, związek pokrewieństwa z głowa rodziny.

A. B.: Powyższe zdania, w całości i we fragmentach, pojawiają się w formie przenikania na osobach z długiego ciągu kobiet i mężczyzn z różnych epok. Jest tu dama z epoki napoleońskiej, jest człowiek z czasów Lutra, młoda czarnoskóra dziewczyna z czasów kolonialnych obwieszona ozdobami. Aktorka filmowa z lat 30. sąsiaduje z tubylcem z Nowej Gwinei. Elegant w cylindrze, współczesna uśmiechnięta młoda kobieta, a zaraz po niej ważny carski urzędnik w mundurze. Mamy swego rodzaju przekrój ludzkości zamieszkującej kiedykolwiek naszą planetę.

P. J.: Potem w obrazie pojawia się „Książka meldunkowa”.

A. B.: Tak, coś zdecydowanie poważniejszego niż luźne blankiety do wypełnienia. Wpis do książki meldunkowej nie przemijał, a strony były policzone, ale zawartość merytoryczna pozostała ta sama: nazwa zakładu, miejscowość, 
numer domu, komisariat. Numer porządkowy, imiona rodziców, zawód i stanowisko, wyznanie, przynależność państwowa, stosunek do powszechnego obowiązku wojskowego, skąd przybył, miejsce zamieszkania, data przybycia, uwagi, adnotacje o karach. Wszystko podsumowane stwierdzeniem zgodności wyciągu z rejestrem mieszkańców. W ikonografii - ciąg dalszy listy osób zamieszkałych: Chińczyk z warkoczykiem, średniowieczny królewicz w koronie, tubylec z Amazonii, współczesny młody mężczyzna: okulary, biała koszula, posągowa dama w woalach z czasów antycznych, marmurowe popiersie rzymskiego cesarza, młoda kobieta z lat 30., młody faraon.

P. J.: Ruch mechaniczny (przyjazdy) ludności od dnia do dnia i czas przebywania. Skąd przybyli, województwo: warszawskie, łódzkie, kieleckie, lubelskie, białostockie. Mieszkańcy: stan cywilny, kawaler, panna, żonaty, zamężna, wdowiec, wdowa, rozwiedziony, rozwiedziona. Wiek: od najmłodszych do najstarszych.

A. B.: Tutaj zgromadziłem różne środki transportu, które pojawiły się na przestrzeni wieków. Kolej, kraina polarna i sanie; średniowiecze: dostojnik podróżuje "salonką" dźwiganą przez dwa konie i w obstawie rycerstwa. Wiek XVIII: znane już i używane są balony. Na morskich falach karawela z wydętymi żaglami. Afryka: długi sznur tragarzy forsujących rzekę, z wody wystają im tylko głowy, na których dźwigają olbrzymie ładunki. Spotkanie dwóch karawan na pustyni. Dwa statki pasażerskie mijają się na rzece. Chiński dostojnik podróżuje w lektyce, którą dźwigają tragarze. Starożytna galera poruszana dziesiątkami wioseł. Współczesny samolot ląduje na lotnisku.

P. J.: Ruch mechaniczny (wyjazdy) mieszkańców i ludności i czas przebywania wedtug poprzedniego miejsca pobytu na terenie gminy, miasta, powiatu. Dokad wyjechali, nazwa wojezództwa. To dosyć podobne do przyjazdów.

A. B.: Nie ma wyjścia, tak musi być. Ale ja te podobieństwa uważam za zaletę. Identyczności oraz ich powtarzanie - to jest jak gdyby fundament ponadczasowego ustroju i jego funkcjonowania; funkcjonowania bez oglądania się na cokolwiek, tak musi być i już. Przez wprowadzanie nowości można tylko popsuć egipską surowość tych tekstów. To tak, jakbyśmy chcieli wzbogacić modlitwę różańcową przez dodanie nowych, bliższych nam motywów. Ikonografia też jest podobna, chociaż w gruncie rzeczy inna: Arab w burnusie prowadzi rower. Karawana wozów przykrytych plandekami, w zaprzęgu woły. Mały parowiec rzeczny, z komina bucha słup dymu. Wielkie miasto z początku XX w., na stalowych filarach biegnie linia kolejki nadziemnej. Współczesna autostrada i pędzący autobus. Arktyka, statki unieruchomione przez okowy lodu. Statek parowy poruszany przez wielkie koła z łopatkami, nowość techniczna z końca XIX w.

P. J.: Ale teraz zupełnie coś nowego.

A. B.: Karta zameldowania dla przybywajacych na pobyt czasowy. Nazwisko, imiona, imiona rodziców, przybyt na pobyt czasowy, skąd przybyt, miejsce zamieszkania, zawód ojca i stanowisko w zawodzie, urodził(a) się dnia, miesiaca, wyznanie, jakim dowo- 
dem się legitymuje. W obrazie ujęcie filmowe noworodka, co chwila pojawiają się zdania z karty w formie napisów.

P. J.: Karta urodzenia. Potwierdzenie zameldowania: przynależność państwowa, stosunek do powszechnego obowiazku wojskowego, stopień wojskowy. Uwagi. Podany w niniejszym fakt urodzenia sie dnia... miesiaca..., w 19... roku, stwierdzam. Maluch już sam staje na nogach i usiłuje opuścić kojec. W tym samym momencie w kadrze zostają na niego nałożone dwa nowe formularze: Adnotacje urzędowe. Zameldowanie przyjąt dnia, miesiaca, roku. Podpis. Karta wymeldowania dla przebywajacych czasowo. Dokąd się wymeldował(a), jeśli zagranica, wskazać miejscowość i kraj.

A. B.: Ilustracje: europejskie metropolie i maleńkie wioski w afrykańskim buszu. Gęsta zabudowa starówek miast historycznych i pojedyncze domki w bezludnej przestrzeni. I bliskie nam obrazki: sielski pejzaż z kaczkami w bajorku oraz widok stolicy z Pałacem Kultury. Przed następnym blokiem ilustracji Karta zameldowania dla przybywajacych na pobyt czasowy. Skąd przybyt, przybyła, jeśli zagranica wskazać miejscowość i kraj. Dalszy ciąg ilustracji: miasta i osady z różnych stron świata. Droga prowadzi przez pustynię do arabskiego miasta na horyzoncie. Miasteczko na Dzikim Zachodzie. Stare duże miasto portowe. Znaczne miasto średniowieczne, opasane szczelnie murem, dużo wież kościelnych. Alpejska osada u stóp olbrzymich skał.

P. J.: Nowa sprawa skierowana do biura ewidencji ludności dotyczy wydania dowodu osobistego.

A. B.: Galeria postaci: kobiety i mężczyźni w różnym wieku. Młoda kobieta w kapeluszu uśmiecha się zalotnie. Egipska rzeźba z kamienia z czasów piramid przedstawia młodą kobietę. Popiersia osób ważnych: wódz rzymski, wódz asyryjski, antyczny filozof - wszyscy z marmuru. Ludzie ze zdjęć, z rycin: młody, łysawy, przeciętny mężczyzna, potem aktor z lat 20. o bardzo intensywnym spojrzeniu, dalej czarnoskóry młodzieniec z kilkoma sznurami koralików na szyi. Arystokrata z XVII w., na piersi ordery. Jeszcze więcej orderów jest na uniformie generała, są i wielkie pagony z frędzelków. Ważny hierarcha, pop, zamiast medali ma na piersi miniatury przedstawiające świętych. Dostojnik turecki w bardzo wysokim, piętrowym turbanie.

P. J.: Wydano dowód osobisty numer, dnia. Pokwitowanie. Dowód osobisty numer, otrzymałem. Biuro Ewidencji Ludności potwierdza wpłate gr. 60 tytułem zwrotu kosztów druku blankietu dowodu osobistego.

A. B.: W tym punkcie bardziej szczegółowo potraktowana jest sprawa wyznania: Ruch mechaniczny (wyjazdy) mieszkańców czasowo przebywajacych wedtug przyszłego miejsca pobytu. Wyznanie: rzymskokatolickie, prawosławne, mojżeszowe, inne. Jako ilustracja - zdjęcia i ryciny przedstawiające świątynie reprezentujące różne wyznania. Wnętrze cerkwi z popem i wiernymi. W kościele rzymskokatolickim ksiądz udziela komunii. Totemy afrykańskie zrobione z czegokolwiek i potężne kamienne głowy z Wyspy Wielkanocnej. Świątynie z zewnątrz: egipska, gotycka, 
meczet, cerkiew, świątynia Azteków, Mekka, ziggurat asyryjski, kamienny krąg w Stonehenge.

P. J.: Przyszła pora na obowiązek wojskowy: Karta wyjazdu. Powiat, gmina, miejscowość lub komisariat, ulica, numer mieszkania. Stosunek do powszechnego obowiazku wojskowego, stopień wojskowy. Numer głównej księgi ewidencji. Karta powrotu. Powiat, gmina, miejscowość lub komisariat. Wiarygodność powyższych danych stwierdzam własnoręcznym podpisem.

A. B.: Dowód obejrzałem i sprawdziłem. Posiada dokument wojskowy, obejrzatem i sprawdziłem. Podpis urzędnika rejestru. Na obrazkach rycerze zakuci w zbroję i współcześni czołgiści. Strzał z broni palnej, chmura dymu. Strzał z kuszy. Zbrojny mongolski na koniu, zbrojny i koń w zbroi z misternych kółeczek, w ręce jeźdźca lanca z rozdwojonym ostrzem. Ciężki karabin maszynowy na kółkach, długa taśma z amunicją z lufy ogień. Drewniana szopa, w niej najprostsza armata. Jeśli wymaga tego sytuacja, można otworzyć jedną ścianę, w innej jest otwór na lufę, czyli urządzenie wyjątkowo kompaktowe. Dwóch rycerzy w kolczugach od czubka głowy aż po stopy, jedynie nosy im wystają; wojownik z buszu ma tylko opaskę na biodrach, a w ręce dzidę. Wojownik antyczny jest w krótkiej koszulce, gołe ręce i nogi, w jednej ręce mała okrągła tarcza, w drugiej miecz. Rycerze z olbrzymimi tarczami na wysokość człowieka oczekują na atak wrogów. XVIII w., wielka bitwa, walka na bagnety, a nad skłębionym tłumem walczących oficer na koniu, wymachuje szablą, dyryguje swoimi żołnierzami.

P. J.: Wypis z aktu ślubu. Wolne od opłaty stemplowej. Urodzony dnia, zamieszkały w, syn (imię ojca), tudzież urodzona dnia, zamieszkała w, miejscowość, gmina, powiat, córka (imię ojca), imię i nazwisko panieńskie matki, zawarli zwiazek małżeński. Zgodność niniejszego, dnia, pieczęć, podpis urzędnika stanu cywilnego.

A. B.: I jeszcze jeden dodatkowy dokument ślubny: Karta zameldowania dla przybywajacych na pobyt czasowy. Zawiadomienie o zawarciu mał̇̇eństwa. Potwierdzenie zameldowania. Pary małżeńskie z Syberii, w futrach. Lata 30.: aktor i aktorka w czułym uścisku. Para Eskimosów, para Papuasów. Lata 20.: ona mocno przytulona do jego boku, na jego piersi rząd odznaczeń. Dwa portrety antyczne, on i ona oddzielnie. Para współczesna: zdjęcie ślubne. Małżeństwo chińskie, małżeństwo afrykańskie: kobieta na głowie ma dzban na wodę. Europejscy państwo młodzi z początku XX w.: ona olbrzymka, on bardzo malutki. Małżeństwo z głębi Afryki niezwykle skąpo ubrane. Lata 20.: słodkie zdjęcie pary aktorskiej.

P. J.: Zgłoszenie zamieszkania. Zmiana adresu. Kwestionariusz. Karta rodzinna. Mężczyzna, kobieta, dzieci, imiona, data i miejsce urodzenia. Adnotacja: Poprzednie miejsce zamieszkania. Data zamieszkania w gminie, data zapisania do rejestru. Nazwisko, prawne miejsce zamieszkania, stan cywilny i imię drugiego z małżonków.

A. B.: Portret rodziny z Afryki: żadnego ubrania nie widać, mężczyzna, kobieta, jedno dziecko. Na następnej rycinie z wieku XVIII rodzina królewska: król, królowa i pięcioro dzieci. Ujęcie filmowe: typowa polska rodzina, mąż, żona i dwoje 
dzieci, starszy syn już pomaga, wyciera talerze, a jego młodsza siostrzyczka jest zabawiana przez rodziców. Początek XX w.: matka z córeczką która trzyma w ręce mały dziecięcy koszyczek. Inne dwie ryciny przedstawiają czarnoskórego chłopca i dziewczynkę z dorzecza Amazonki. Rodzina Eskimosów: mąż, żona i syn pozują jak wszyscy. Rodzina z Afryki Środkowej: mąż, żona, dziecko - półnadzy, mężczyzna pozuje ze strzelbą. Matka i córka z Japonii. Wiek XIX, obrazek sielski: matka i córeczka na ławce w plenerze. Rodzina z Dalekiego Wschodu przed domem, dwa pokolenia. Inni z dalekiej Północy mają troje potomków. I jeszcze scena z wiejskiego domu, wiek XIX: matka, mały chłopiec siedzący na podłodze i kotek, który podjada $\mathrm{z}$ miski chłopca.

P. J.: Ruch naturalny mieszkańców oraz ludności czasowo przebywajacej, wg zawodów: stużba domowa, handlowcy, finansiści, zawody wolne. Zawód: robotnik, rzemieślnik, stużba, handlowiec, finansista, urzędnik, nauczyciel, zawód wolny, nieznany. Zawód i stanowisko w zawodzie stanowiące główne źródło utrzymania.

A. B.: Zaczyna się od romantycznego zawodu rybaka; dwaj rybacy stojący na łódce wyciągają sieci. Gdzieś w tropikach skąpo przyodziany czarny mężczyzna w niezwykle prymitywnym warsztacie wykonuje pracę tkacza. Nieco dalej tkalnia z czasów łódzkiej ziemi obiecanej. Praca górnika, hutnika, ale takiego przedpotopowego. Laboratorium chemiczne: w szklanych naczyniach zachodzą reakcje. Pielęgniarka sterylizuje narzędzia chirurgiczne, a za jej plecami już przygotowany stół do operacji. Inne miejsca pracy: gorzelnia, huta, centrala telefoniczna, piekarnia. Dwaj zakonnicy, jak gdyby od św. Franciszka, podczas orki: woły ciągną pług. Egipscy albo asyryjscy robotnicy z ładunkiem kamieni na plecach pną się po pochyłości powstającego obiektu. Murarz z epoki PRL-u buduje mur z cegły. W hucie szkła robotnicy formują wielką banię.

P. J.: Karta wymeldowania dla czasowo przebywajacych w hotelach i tym podobnych zakładach oraz miejscowościach letniskowych, kuracyjnych itp. Nazwisko i imię. Skad przybyt. Wyprowadzit się dnia, miesiaca, roku. Osoby towarzyszace. Jak długo przebywat (a). Pieczęć zakładu, względnie podpis prowadzacego meldunki. Adnotacje urzędowe: Wymeldowanie przyjęto dnia, miesiaca, roku.

A. B.: Cały repertuar zabiegów sanatoryjnych: ręce i nogi kuracjusza w kuwetach z wodą i rezonansem. Specjalna klatka do leczenia polem magnetycznym, w klatce kuracjusz, a obok, na zewnątrz osoba dozująca prąd. Specjalny aparat do leczenia słuchu. Naświetlanie lampą kwarcowa, kuracjusze w ciemnych okularach krążą w kółko. Zajęcia na powietrzu: rano wspólna gimnastyka w piżamach, w południe panie w kostiumach kąpielowych ćwiczą oddzielnie, rzucają ciężką piłką lekarską, wiosłują na sucho, podciągają się na drążku. Panowie ćwiczą na sali, rozciągają gumy, wiosłują.

P. J.: Wyprowadził się, opuścił miejsce czasowego pobytu. Potwierdzenie wymeldowania. Dowód zmiany miejsca zamieszkania. Przesyła się gminie nowego miejsca zamieszkania osoby wymeldowanej. W związk z powyższym zarząd gminy: Punkt pierwszy - Niepotrzebne skreślić - Prosi o nadestanie dowodu zamieszkania wzoru B. Punkt drugi 
- Niepotrzebne skreślić - Potwierdza odbiór zawiadomienia wzoru C. Punkt trzeci-Niepotrzebne skreślić - Zarząd gminy uprasza nadto o nadesłanie brakujących zgłoszeń wzoru numer 2, wzoru 2A. - Dochodzenie. Ponieważ syn, córka, wraz z... Czy rzeczywiście wyżej wymieniony zajmowany lokal opuścit, że wyżej wymieniony(eni) rzeczywiście nie zamieszkuje(ja), nie zostat wymeldowany, karane będzie zgodnie z artykułem 25. Pokwitowanie $z$ doręczonego adresatowi pisma. Pokwitowanie z doręczenia odpowiedzi w Biurze Ewidencji Ludności.

A. B.: Hala maszynistek. Zbliżenie na maszynistki i maszyny. Informacja o przedłożeniu kartek sprostowania. Zbliżenie druku. Podpisy, pieczęć. Kartkowanie zeszytu z notowaniem korespondencji.

P. J.: Zawiadamiam, że mieszkania nie zlikwidowat, wyjechat czasowo, z tego adresu zostat wymeldowany dnia, roku, do. Lokal opuścit, lecz dotychczas wymeldowany nie zostat, wobec czego załącza się egzemplarz zgłoszenia zmiany miejsca zamieszkania. Niepotrzebne skreślić.

A. B.: Archiwum, regały, pojawiają się akta. Archiwum widziane z góry, regały z dokumentami. Pojawia się archiwista.

P. J.: Dochodzenie. Od wszelkich osób, mogących udzielić potrzebnych wiadomości karane będzie zgodnie z artykułem 25. Pokwitowanie z doręczenia odpowiedzi. Otrzymałem dn. (podpis adresata). Pokwitowanie z doręczenia odpowiedzi. Podpis i pieczęć urzędnika.

A. B.: W tle odpowiedni druk urzędowy, panorama. Korespondencja staje się coraz częstsza. Zbiory archiwalne, pakieciki wezwań i potwierdzeń. Urzędnik studiuje akta, robi wypisy.

P. J.: Odpowiadajac na zawiadomienie wzoru A/C, wszczęte zostało... W zwiazku... syn/córka... Czy wymieniony rzeczywiście tam zamieszkał (zamieszkiwat) w ciagu trzech dni od daty otrzymania.

A. B.: Stanowisko z korespondencją dziesiątki kopert. Urzędniczka otwiera je, segreguje.

P. J.: Ponaglenie. Przesyła się gminie, która w terminie 21 dni nie nadestała odpowiedzi na zawiadomienie wzoru A lub wzoru C. Powołujac się na paragraf 31 rozporzadzenia Ministerstwa Spraw - spowodowanie przyśpieszenia odpowiedzi zawiadamiam, że według oświadczenia (wymienić osobę udzielająca informacji) wyżej wymieniony: a) zamieszkuje w (podać szczegółowy adres); b) opuścit dotychczasowe miejsce zamieszkania dn. i nie powrócił udajac się, nie wiadomo dokad; c) powrócił dn... $i$ został zameldowany dn... na kartach wzór nr... Oświadczyt, że przebywał czasowo w... Niepotrzebne skreślić.

A. B.: To już jest straszenie karą. Doniesienie karne o ewidencji $i$ kontroli ruchu ludności. Syn/córka, lat, zawód dopuścit się naruszenia przepisów. Świadkowie (lub inne dowody wykroczenia). 
P. J.: Faktycznie, wyznaczone zostają kary finansowe. Winę ponosi prowadzący meldunki.

A. B.: W warstwie obrazowej: przedstawiciele ludzkości (35 osób), eleganckie kobiety z różnych krajów i stuleci, wielcy wodzowie i aktor komediowy, osoby w ciężkiej zbroi i ubrani bardzo lekko mieszkańcy ciepłych krajów, osoby szczelnie zakapturzone i osoby posągowe, z marmuru, rzymscy senatorowie.

P. J.: Karta zgonu dla przebywajacych czasowo.

A. B.: Dwadzieścia postaci zamyka oczy i zostaje usuniętych z kadru, co jest równoznaczne z przemijaniem. Nazwisko, imiona. Zmarł dnia, miesiaca. Miejsce zgonu (jeśli za granica wskazać kraj). Wiarygodność powyższych danych własnoręcznym podpisem stwierdzam. Uwagi: Podany w niniejszym fakt $d n . . ., m-c a . .$. stwierdzam. Adnotacje urzędowe: wymeldowanie przyjąt $d n \ldots$...

P. J.: Wyprowadził się, opuścił miejsce czasowego pobytu dnia... miesiaca... roku... został wymeldowany z domu nr... mieszkania nr... przy ulicy... Komenda Państwowej Policji. Podpis urzędnika dnia, miesiaca, roku.

A. B.: Czarne chmury burzowe zaciemniają kadr. Zaraz potem błyskawice, pioruny.

P. J.: Zwrotne potwierdzenia doręczenia. Potwierdzam odbiór drugostronnego nakazu karnego. Nie mogłem doręczyć z powodu: a) śmierci adresata, $b$ ) iż adresat we wskazanym domu jest nieznany, c) iż adresat opuścit wskazany dom na stałe, przenoszac się do..., d) iż adresat opuścił wskazany dom na stałe, udajac się do miejscowości, której ustalić nie mogłem (ostatni punkt lektor odczytuje dwukrotnie). Kula ziemska przechodzi w obraz gwiaździstego nieba, potem obraz się rozjaśnia i ukazuje się ciastowata planetoida; wkrótce rozpada się ona na małe cząsteczki. Po przenikaniu ekran wypełnia ciemne niebo z jasnymi punktami - gwiazdami.

Koniec jak w kinie klasycznym?

A. B.: Wersja laicka: idziemy nie do nieba, tylko w kosmos i bez dokumentów. Jak uchodźcy.

Nie ulega wątpliwości, że do szerokiej widowni docierają jedynie filmy fabularne Andrzeja Barańskiego. Fakt ten wiąże się naturalnie z pewnymi konsekwencjami, jak chociażby nieunikniona stereotypizacja. Trzeba jednak przyznać, że dość ujednolicony sposób myślenia o kinie Barańskiego jest $\mathrm{w}$ dużej mierze uzasadniony. Reżyser w filmach pełnometrażowych stworzył określony styl, związany z przestrzenią i bohaterem o charakterze prowincjonalnym. Przyzwyczaił zarówno widzów, jak i krytykę do klisz fabularnych, adaptacji określonej literatury, nietypowej dramaturgii, elementów autobiograficznych oraz niespiesznego rytmu wydarzeń. Niewiele zmieniał, a modyfikacje nie stanowiły podstawy zwrotu w jego karierze. W zgodnej opinii filmoznawców zasilił szeregi autorów kina polskiego zwanych twórcami osobnymi, którym obce są formacje artystyczne, pokoleniowe 
wystąpienia czy manifesty; jeśli już, to pisane w pojedynkę, jak tekst pt. Moje kino opublikowany przez reżysera w 1985 r. w numerze 29 czasopisma „Film”.

Barański nie przestawał jednak realizować scenariuszy oryginalnych. Przebieg jego kariery jest dwutorowy. Z jednej strony regularnie powstawały tradycyjne adaptacje, $\mathrm{z}$ drugiej utwory awangardowe w postaci etiud studenckich (Kręte ścieżki; Dzień pracy; Podanie; Księżyc). Wydaje się, że właśnie w obrębie tych drugich znajduje się wciąż dużo do odkrycia i opisania; w przeciwieństwie do fabuł, których temat został - z perspektywy filmoznawczej - już niemal wyczerpany. Wywiad Filmy do czytania może służyć jako przykład zerwania z ciągłością jednoznacznej kategoryzacji dorobku twórcy Księstwa. Spojrzenie na niezbadane dotąd utwory ma jeszcze jeden walor poznawczy - w rozmowie sam Barański zrywa poniekąd ze swoim dotychczasowym wizerunkiem. Gdy tłumaczy sens filmów do czytania, staje się bardziej nonszalancki, sięga po subtelny humor, otwiera się na inny świat, a także - last but not least - poświęca dużą uwagę strukturze formalnej. Wszystko to czyni (wbrew pozorom nie w pełni rozpoznaną) twórczość reżysera bardziej tajemniczą i fascynującą.

${ }^{1}$ P. Marecki, Barański. Przewodnik Krytyki Politycznej, Wydawnictwo Krytyki Politycznej, Warszawa 2009, s. 263.

${ }^{2}$ M. Świetlicki, Jeden, Wydawnictwo EMG, Kraków 2013, s. 34.

\footnotetext{
${ }^{3}$ Pisownia oryginalna. Ten sposób zapisu został zachowany we wszystkich fragmentach, w których zacytowana jest ścieżka dialogowa filmu.
}

\section{Paweł Jaskulski}

Absolwent Wydziału Polonistyki Uniwersytetu Warszawskiego, asystent w Zakładzie Retoryki i Mediów w Instytucie Polonistyki Stosowanej tej uczelni, instruktor w Oddziale Doboru i Selekcji Księgozbiorów w Bibliotece Publicznej m.st. Warszawy - Bibliotece Głównej Województwa Mazowieckiego. W przeszłości współpracował z portalem internetowym historia.org (recenzje książek i filmów). Przygotowuje do druku rozprawę doktorską pt. Trórczość filmowa i literacka Fanusza Nasfetera, napisaną pod kierunkiem prof. Krzysztofa Kopczyńskiego. Należy do Polskiego Towarzystwa Badań nad Filmem i Mediami. Współorganizator wielu konferencji, m.in. ogólnopolskiej O poprawie kina polskiego oraz międzynarodowej Edukacja filmowa i medialna w Polsce $i$ świecie. Rozwiazania systemowe oraz studia przypadków. W pracy naukowej koncentruje się na takich zagadnieniach, jak: nowy kanon kina polskiego, kino gatunkowe, edukacja medialna, literatura współczesna, muzyka rockowa. Publikował między innymi na łamach czasopism „Media - Kultura - Komunikacja Społeczna”, „Twórczość”, „Odra”. Współredaktor interaktywnego tomu Różne oblicza edukacji audiowizualnej (2016). 


\section{Bibliografia}

Marecki, P. (2009). Barański. Przewodnik Krytyki Politycznej. Warszawa: Wydawnictwo Krytyki Politycznej.

Świetlicki, M. (2013). feden. Kraków: Wydawnictwo EMG.

\author{
Keywords: \\ new canon \\ of Polish cinema; \\ educational film; \\ animation; \\ documentary film; \\ experimental \\ cinema; \\ Andrzej Barański
}

\begin{abstract}
Paweł Jaskulski

Films for Reading

In the interview Films for Reading, the director Andrzej Barański tells us about a lesser-known part of his work, namely three short films. Their uniqueness consists in the combination of different techniques - documentary, animation, educational - but also in the concept mentioned in the interview title. In The Stream (Potok, 1985), Sentimental Education (Edukacja sentymentalna,1986), and Temporary Residence (Pobyt czasowy, 2004), the stylistic modes - besides the iconography used - are contained in words, such as lexicon entries, guidelines, documents (applications, registrations etc.). The spectators have an opportunity to actually "read" these films. Such reading might lead them to various interpretations. The interview is informative, but even more so - in line with the idea and the spirit of the film works - it is an attempt to "read" the films together with the author/director. In the course of discussion, various means of expression are exposed, in particular the art of film editing. The entire interview can be seen as part of research on previously understudied areas in the Polish cinematic history.
\end{abstract}

